\title{
Large-tree removal in a mixed-conifer forest halves productivity and increases white fir
}

by Robert A. York

Removing all large trees without planning to replace them with either planted or naturally regenerated younger trees (i.e., high-grading) is widely thought to have negative consequences on a forest's productivity and species composition, but no previous studies in California had evaluated this assumption. To make such an evaluation, I measured productivity and canopy species composition shifts following the repeated removal of large trees and compared the results with those from two other basic forest harvest methods: thinning from below and single tree selection. Timber productivity was substantially lower with large-tree removal ( 0.65 thousand board feet per acre per year) than with the other methods (averaging 1.33 thousand board feet per acre per year), which included the no-harvest control, where yield was zero. Large-tree removal also resulted in more species change, with white fir increasing in the canopy and ponderosa pine decreasing.

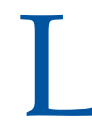

arge trees in forests are highly valued, often because of their ecological roles in sustaining wildlife habitat and biodiversity (Franklin et al. 2002). Their size, however, also makes them highly valued for timber because of their high wood quality and the considerable gains in logging efficiency and volume production when harvesting large logs. In many Western forests, a variety of regulatory, economic and ecological factors (e.g., threats of large-tree harvest limits, lumber demand and competitionrelated mortality) have made large trees more rare than they were a century ago (Hagmann et al. 2013; Lutz et al. 2009). The repeated harvest of the majority of large trees in a stand without steps to replace them obviously contributes to this large-tree scarcity.

Repeated large-tree removal is an especially attractive harvesting practice in forests on nonindustrial private lands, where timber revenue can be marginal because of the small scale of harvests. Removing large trees can make a harvesting operation much more feasible and profitable in the short run; the level of expertise needed for tree marking is low and the

Online: http://californiaagriculture.ucanr.edu/ landingpage.cfm?article=ca.v069n01p27\&fulltext=yes doi: 10.3733/ca.v69n01p27 yield per tree is high. Logging efficiency is therefore maximized and harvest costs are lower. However, there are potential negative long-term effects of large-tree removal, including the impacts on wildlife and biodiversity and also on timber productivity and the tree species composition of the forest. Because of the relatively high volume production of large trees (e.g., Stephenson et al. 2014), removing only large trees may result in a net decline in stand-level volume growth and therefore a decline in merchantable volume (timber production) over time. The removal of large trees may also cause genetic bottlenecking if they are from the same cohort as the smaller trees that are left behind and the smaller trees are genetically predisposed for slower growth.

Timber management on nonindustrial lands in California rose steadily between 2000 and 2010 (Cal Fire 2010), and recent legislation that expands the acreage limits for nonindustrial harvest planning (Assembly Bill 904) could significantly increase harvest activity. This trend makes clear the need to understand the

Despite the potential for long-term negative impacts, large-tree removal is still common throughout the United States. Right, a typical stand where most large trees have been removed, leaving only small- and medium-sized trees behind.

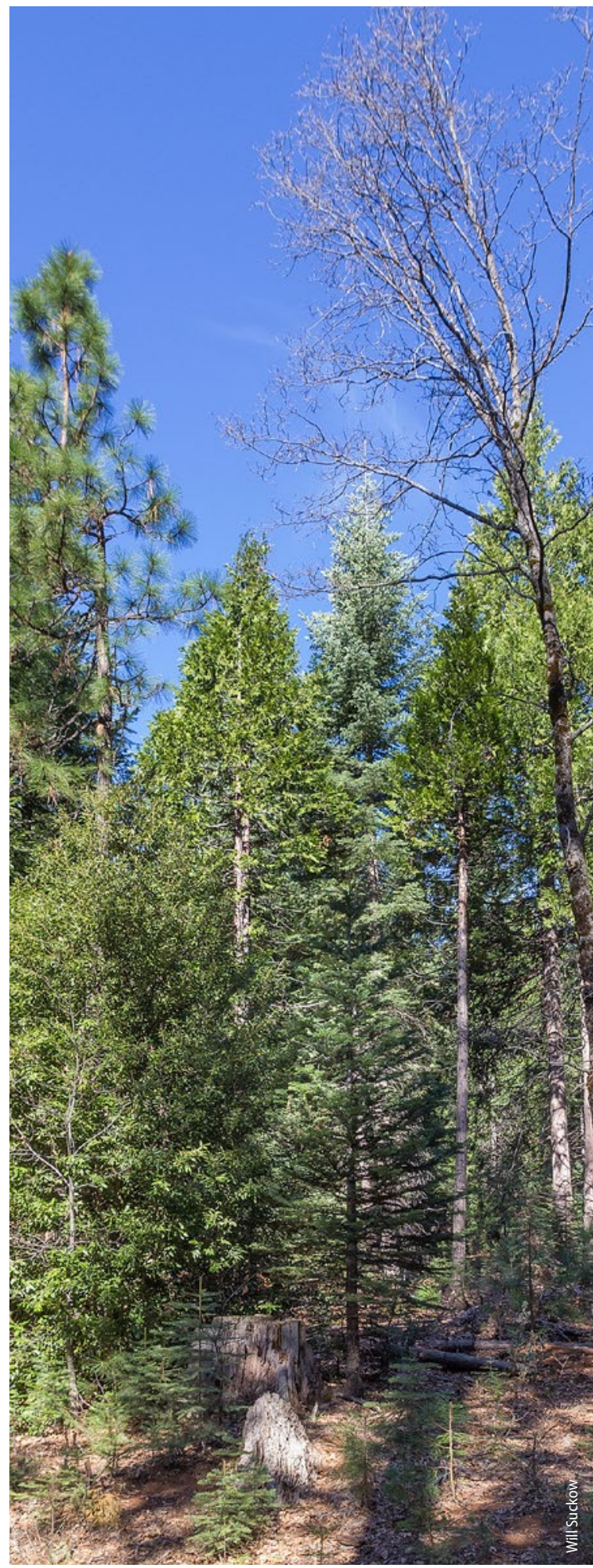


tradeoffs between different management approaches on these lands.

This study addresses the consequences of repeated large-tree removal compared to those of three other timber harvesting methods (thinning from below, single tree selection, and no harvests). I define large-tree removal as cutting all or most trees above a specified tree size (typically, a specific diameter at breast height, or $\mathrm{DBH}$ ) and leaving all trees of smaller size. Various regional and technical terms have been used to describe this method of harvesting, including diameter limit cutting, thinning from above, overstory removal and the more pejorative terms high-grading and dysgenic selection. Clear-fell harvesting, which removes trees of all size classes including large trees, is a different form of harvesting and is not addressed here.

Despite a history of exploitative practices that focused on the cutting of the largest trees and the potential for long-term negative impacts, large-tree removal is still common throughout the United States. In hardwood forests of the Northeastern states, for example, studies highlight the benefits of large-tree removal, including its relative simplicity in terms of implementation ("cut all trees greater than 24 inches $\mathrm{DBH}^{\prime \prime}$ ), its economic advantages and even the ecological gains related to forest health (Buongiorno et al. 2009). Managers in this region also understand the negative effects of largetree removal because of the empirical studies that have tracked species composition and productivity effects (Angers et al. 2005; Erickson et al. 1990; Hawley et al. 2005; Kenefic et al. 2005; Kern et al. 2006).

Prior to this study, however, no such exploration of the effects of large-tree removal had been done in California forests. Some regulations that limit largetree removal in California are in place.

For example, there are restrictions on cutting trees greater than 30 inches DBH on many federal forestlands, and permits for selective harvests on private lands require that trees greater than 18 inches $\mathrm{DBH}$ constitute a minimum amount of basal area (the cross sectional area of stems at breast height) per acre. Very little published evidence from experimental trials exists to back up claims of the negative or positive effects of large-tree removal on productivity and species composition. I address the need for more information by reporting results from a long-term study at Blodgett Forest Research Station (BFRS) designed to compare repeated large-tree removal with three harvesting methods that maintain a relatively intact canopy over time: removing only smaller trees, selecting trees of all size classes, and not removing any trees.

\section{Sierra Nevada study area}

BFRS is on the western slope of the central Sierra Nevada in California (38 $52^{\prime}$ north latitude and $120^{\circ} 40^{\prime}$ west longitude); the elevation is 4,260 feet (1,298 meters). The climate is Mediterranean, with dry, warm summers and mild winters. Average monthly maximum temperatures during the summer months is $79^{\circ} \mathrm{F}\left(26^{\circ} \mathrm{C}\right)$; average monthly minimum temperatures during winter months is $34^{\circ} \mathrm{F}\left(1^{\circ} \mathrm{C}\right)$ over the past 30 years measured on-site. Annual precipitation averages 65 inches (165 centimeters), most coming from rainfall during fall and spring months. Before the imposition of fire suppression policies, the median fire interval in the area was 9 to 15 years (Stephens and Collins 2004). In general, slopes are less than $30 \%$. The

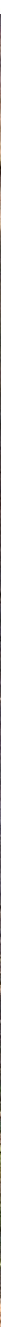


soil developed from granodiorite parent material and is productive for the region. Heights of codominant canopy trees typically reach 89 to 112 feet ( 27 to 34 meters) in 50 to 60 years.

Vegetation at BFRS is dominated by a mixed-conifer forest type (Barbour et al. 2007) composed of variable proportions of white fir (Abies concolor), incense cedar (Calocedrus decurrens), Douglas fir (Pseudotsuga menziesii), sugar pine (Pinus lambertiana), ponderosa pine (Pinus ponderosa) and California black oak (Quercus kelloggii). Like much of the mixed-conifer forest in the Sierra Nevada, the study area was clear-fell harvested for timber extraction in the early 1900s, and the subsequent forest developed from sparse residual trees and advanced regeneration. By 1980, the beginning of the period used for this study, stands were comprised of continuous tree canopies of mixed species (i.e., structures were typical of second-growth forests).

Treatments for this study were located throughout the $\sim 2,900$ acres $(1,734$ hectares) of the BFRS main tract. In the 1970s, BFRS was allocated into managed stands, the boundaries of which were formed by small drainages and ridges. These stands were assigned to various management strategies to represent a broad gradient of silvicultural practices, and each stand has been managed with the same treatment regime consistently over time. The same manager wrote harvest prescriptions throughout the time period used for this study (1980 to 2006), and the same equipment operator was used for all logging.

\section{Four harvest strategies}

Four continuous cover harvesting strategies are reported on in this study to represent the options that private landowners have when the primary objective is to generate periodic timber revenue while maintaining continuous canopy cover. Maintaining continuous canopy cover may be done to meet aesthetic and wildlife habitat objectives, or it may be required by easements or constraints from permitted nonindustrial management plans. The four study treatments were as follows:

1. A control treatment with no harvests of any size class (including salvage harvesting).
2. Large-tree removal: The largest-diameter trees were preferentially removed until a postharvest residual density target of between 125 and 150 square feet per acre ( 29 and 34 square meters per hectare) was reached. Re-entry (the next harvest) occurred when density reached approximately 200 to 250 square feet per acre (46 to 57 square meters per hectare).

3. Thinning from below: The smallestdiameter merchantable trees were removed until a postharvest residual density target of between 125 and 150 square feet per acre was reached. Reentry occurred when density reached approximately 200 to 250 square feet per acre.

4. Single tree selection: Trees of all size classes were removed, in rough proportion to the stand-level density of different size classes before harvest. All size classes were maintained over time. Postharvest residual density was approximately 100 to 125 square feet per acre (23 to 29 square meters per hectare). Re-entry occurred when density reached approximately 200 to 250 square feet per acre.

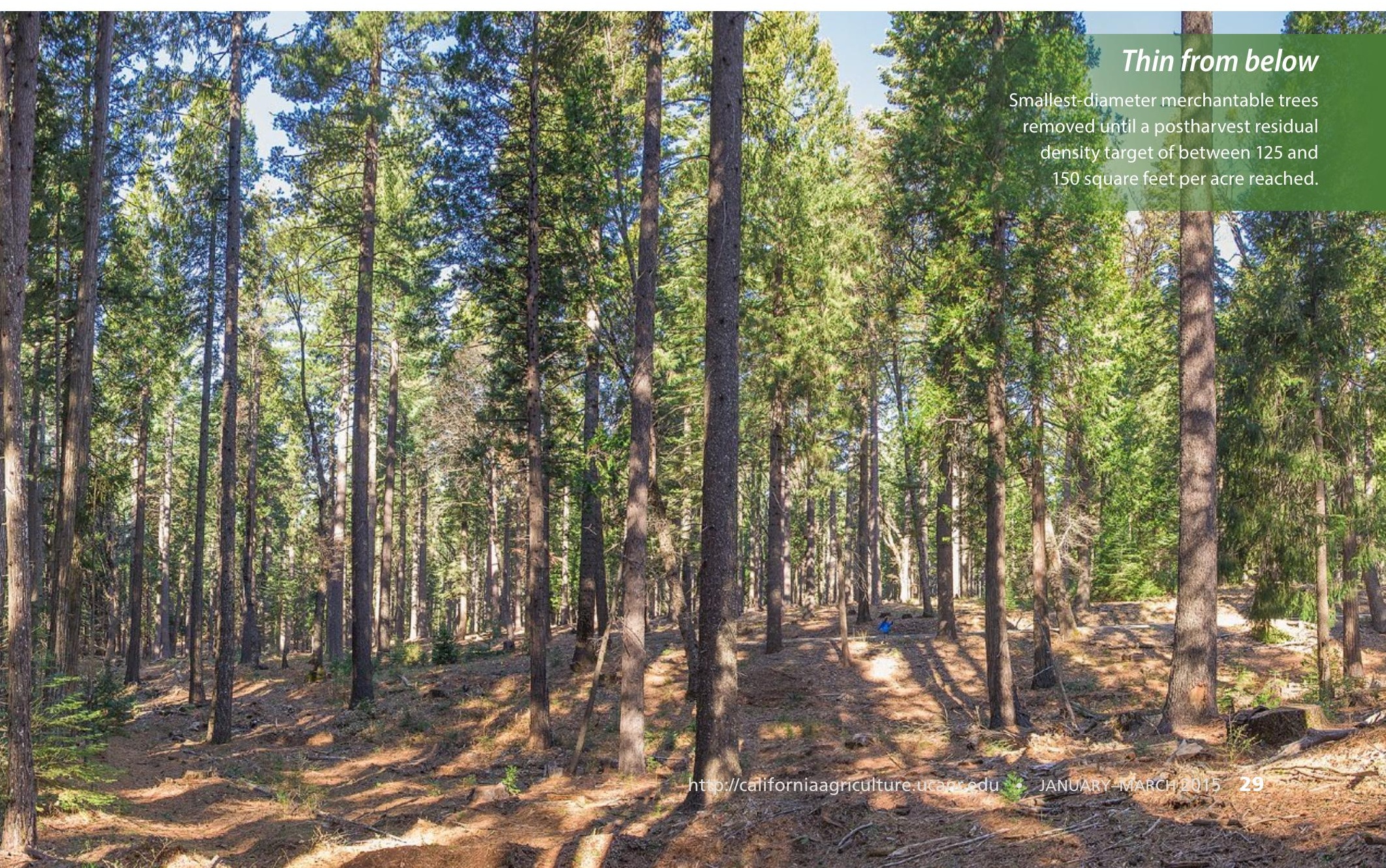


measurements, its volume did not contribute to the second measurement. For the control stands, I used the time between measurements that most closely matched the time between measurements from the harvested stands. In the harvested stands, net volume was sometimes negative if standing postharvest volume after the second harvest was less than standing volume prior to the first harvest. For the controls, net volume was always positive because these second-growth stands are still aggrading following regeneration harvests a century ago (Eitzel et al. 2013).

Harvested yield was calculated from the plot measurements, which were always done immediately following harvests. During postharvest surveys, trees that were removed during the harvest were recorded. The volume of removed trees was calculated from preharvest measurements and were totaled for each plot. Plots were then averaged across stands to give stand-level yield.

Finally, growth plus yield $(G+Y)$ was calculated by adding the yield occurring from the two harvests to the net growth that occurred during the study period. Yield for the control stands was always zero since there were no harvests. $G+Y$ was analyzed with the objective of detecting any differences in timber productivity between treatments. Analysis of covariance (ANCOVA) was used, with $G+Y$ as the response variable, treatment as the predictor variable, and initial stocking level (the amount of standing volume at the beginning of the study period) as a covariable.

Initial stocking level was included as a covariable to account for any differences in productivity during the study period that were related to different initial volume density. Although there was no significant difference between treatments in terms of initial stocking level, it was included in the analysis since productivity is typically strongly associated with stocking (O'Curtis et al. 1997). Treatment effects were judged as significant at $P<0.05$. Post hoc comparisons between pairs of treatments were made with Tukey's HSD tests (Zar 1999). Analyses were done using JMP 9.0 statistical software (SAS, Cary, NC).

\section{Measuring species composition}

I assessed change in species composition by measuring change in relative species abundance. This was defined as the change in relative basal area of trees $>10$ inches DBH for a given species from the beginning of the study period to the end of the study period. For example, if a stand's total basal area had a relative proportion of 0.50 represented by Douglas fir prior to harvests and then 0.40 following the harvests, the change in relative basal area was -0.10 . An overall change in relative basal area for each of the treatments was tested with ANOVA. Each harvest method was tested separately, with species as the independent variable and change in relative species basal area as the dependent variable. This served to evaluate whether there was an overall change in species composition for any of the treatments.

A post hoc evaluation of the degree to which individual species had changed was made for those treatments that were significant. This was done using a conservative approach: Individual species were judged to have changed significantly if the confidence interval of the amount of change did not overlap with zero (Ford 2007).

\section{Productivity decline, species change}

The treatments had a significant effect on $\mathrm{G}+\mathrm{Y}$ for both merchantable volume $(P=0.02)$ and total stem volume $(P=0.02)$.

In the control stands, although yield was zero, productivity was similar to or greater than in stands harvested by thinning from below or single tree selection. Even though stocking was quite high (mean basal area $>300$ square feet per acre), volume productivity was still high, as the stand continued to grow positively in standing volume over time.

Timber productivity was significantly reduced in the stands that were harvested by large-tree removal. Average merchantable volume in those stands was 0.66 thousand board feet per acre per year and 1.38 thousand board feet per acre per year for all the other stands combined (fig. 1A). Stem volume was 108 cubic feet per acre per year in stands harvested by large-tree removal and 214 cubic feet per acre per
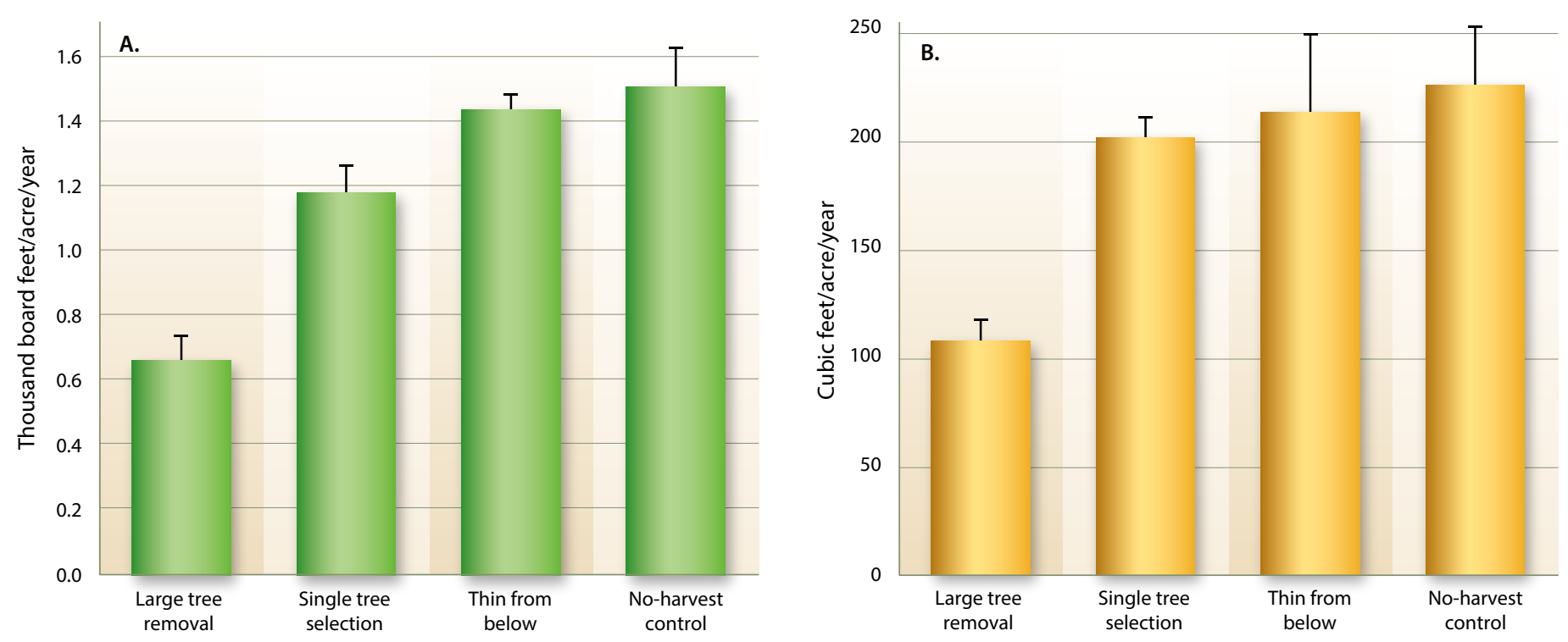

Fig. 1. Means and standard errors of growth + yield $(G+Y)$, expressed in merchantable board feet $(A)$ and total stem volume $(B)$, among four treatments after two harvests at Blodgett Forest Research Station, CA. 
year for all the other stands combined (fig. 1B). Merchantable timber productivity was also lower in large-tree removal stands with pairwise comparisons to all other treatments. Stem volume in largetree removal stands was lower than in the stands that were harvested by single tree selection, but there were no other differences detected between pairs of treatments. Initial stocking level was not a significant influence on volume productivity. However, for merchantable volume it was suggestive $(P=0.10)$ that productivity in general increased with initial stocking, as would be expected.

Large-tree removal led to a notable change in canopy species composition and was the only treatment that led to a detectable change in overall species composition (fig. 2). Notably, black oak and especially white fir increased in relative basal area in stands harvested by largetree removal. This increase was countered by a relative decrease in ponderosa pine. Other minor changes occurred but were not significant. Species composition of the no-harvest controls was relatively unchanged over the study period (table 1).

\section{Long-term losses}

Preferentially removing only the largest trees in forests can be an effective way to increase short-term profit, but the longterm effects measured in this study were decidedly negative: Timber productivity was cut in half, and white fir increased while ponderosa pine decreased. If forest management objectives include maintaining a high productivity and a canopy species composition that is similar to the time before fire suppression, then large-tree removal as practiced in this study deserves the pejorative name high-grading.

The reason for the change in species composition in these stands is ostensibly the outcome of the marking priority placed on large trees. Ponderosa pine and Douglas fir, both relatively fast growing, decreased in the canopy because they were the largest species at the time of harvest. The resulting increase in white fir is misaligned with the conventional objective of preferring a species composition closely associated with pre-fire
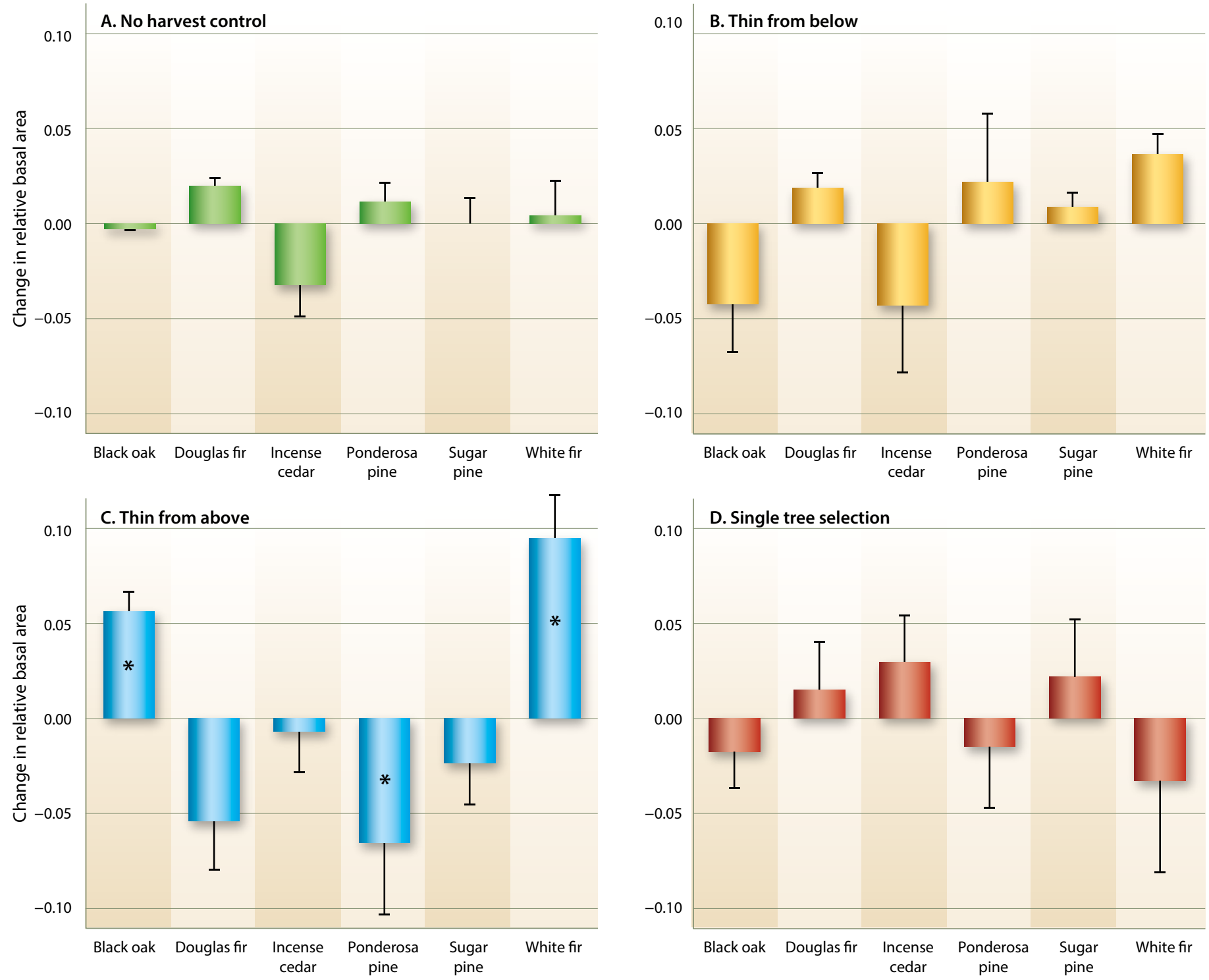

Fig. 2. Change in relative species composition in four treatments after two harvests at Blodgett Forest Research Station, CA. Large-tree removal was the only treatment with a detectable shift in species composition. Bars are means with standard error whiskers. Asterisks denote those species where the $95 \%$ confidence interval of the mean change did not overlap with zero. 
suppression conditions. The widespread increase in white fir across intact Sierra Nevada forests (e.g., Ansley and Battles 1998) has been exacerbated by largetree removal. It has come at the cost of ponderosa pine, which was by most accounts extremely more common prior to fire suppression (e.g., Hagmann et al. 2013). The other methods studied were arguably only slightly better in terms of species composition, as they also did not actively recruit ponderosa pine in the canopy.

The reason for the decline in timber productivity is less clear. One likely contributing factor is genetic bottlenecking. The second-growth stands used in the study are from a single cohort that derives from railroad logging disturbances approximately 100 years ago. Larger trees in second-growth forests such as these are often no older than their smaller neighbors. To the extent that genetic influences caused these trees to be larger, their removal would result in a proportionate dysgenic selection. This potential negative genetic effect of large-tree removal has long been recognized (Daniel et al. 1979) but seldom tested. Hawley et al. (2005) noted an increase in rare allele frequency following large-tree removal but also associated genetic factors with a loss of productivity in Northern hardwood stands.

The other likely contributing factor is in the difference in growth capacity

TABLE 1. Relative basal areas (percentages) by species among different harvest methods before and after two harvest entries at Blodgett Forest Research Station, between 1980 and 2006

\begin{tabular}{|c|c|c|c|c|c|c|c|c|c|c|c|c|}
\hline \multirow[b]{2}{*}{ Treatment } & \multicolumn{2}{|c|}{ Black oak } & \multicolumn{2}{|c|}{ Douglas fir } & \multicolumn{2}{|c|}{$\begin{array}{l}\text { Incense } \\
\text { cedar }\end{array}$} & \multicolumn{2}{|c|}{$\begin{array}{l}\text { Ponderosa } \\
\text { pine }\end{array}$} & \multicolumn{2}{|c|}{ Sugar pine } & \multicolumn{2}{|c|}{ White fir } \\
\hline & Pre & Post & Pre & Post & Pre & Post & Pre & Post & Pre & Post & Pre & Post \\
\hline & . & $\cdots$ & $\cdots$ & $\ldots$ & $\cdots$ & $\cdots$ basc & rea $(\%$ & $\cdots$ & $\cdots$ & .... & * & $\cdots$ \\
\hline Large-tree removal & 13 & 18 & 19 & 14 & 35 & 35 & 15 & 8 & 3 & 0.1 & 14 & 23 \\
\hline $\begin{array}{l}\text { Single tree } \\
\text { selection }\end{array}$ & 8 & 6 & 20 & 22 & 21 & 24 & 13 & 12 & 10 & 12 & 28 & 24 \\
\hline $\begin{array}{l}\text { Thinning from } \\
\text { below }\end{array}$ & 10 & 6 & 6 & 8 & 28 & 24 & 35 & 37 & 1 & 2 & 19 & 23 \\
\hline Control: no harvest & 4 & 4 & 16 & 18 & 27 & 24 & 15 & 16 & 9 & 9 & 27 & 28 \\
\hline
\end{tabular}

between large and small trees. Large trees can be exceptional in their capacity to produce stem volume, both in intact forests (Stephenson et al. 2014) and following removal of competing vegetation (York et al. 2010). However, relatively high stem growth efficiency has also been observed in midstory trees in mixed-conifer forests (Gersonde and O'Hara 2005), causing uncertainty that growth efficiency was a primary contributing factor to the decline in productivity in the large-tree removal stands in the study.

Lastly, it may be that the large trees removed had, by chance, exclusive access locations, with high levels of underground resources. These sweet spots would seemingly be only a short-term contributor, however, as neighboring trees would eventually occupy much of the high-value growing space made available by the vacancy of the large trees.

It is likely a combination of factors that caused the productivity decline. The many factors that make a tree grow faster or slower prior to a harvest - genes, microsite, neighborhood effects and luck - continue to influence growth of trees remaining after a harvest.

\section{Landowner options}

To restore lost productivity and species composition in forests that have been harvested by large-tree removal, landowners have several options. While thinning from below may intuitively seem to be the countermeasure to large-tree removal, it would not address the impacts of genetic bottlenecking. Nor would it address the shift toward white fir, unless it was an

\section{Clearcut}

This method, where all trees are removed and the site planted, is more common on industrial lands. Nonindustrial landowners may alternatively choose group selection, where openings are smaller. 
intermediate step toward regenerating ponderosa pine in the future. Clearcutting and planting would be a way to start over, but nonindustrial landowners tend to avoid this, either because of their aesthetic objectives or because the permit options available to them (nonindustrial timber management plans and working forest management plans) do not allow evenaged methods.

A group selection harvest method that creates smaller openings of about an acre in size that are then planted can be a viable option (York et al. 2004), especially if fast-growing trees of native species, including ponderosa pine, are planted in the openings and are managed by thinning and control of other vegetation. Harvest by single tree selection, although more marginal in terms of ponderosa pine regeneration, may also work if designed and implemented carefully (York et al. 2011). CA

R.A. York is Research Stations Manager and Adjunct Assistant Professor of Forestry in the UC Center for Forestry and Department of Environmental Science, Policy, and Management at UC Berkeley.

Frieder Schurr provided assistance with growth modeling. Bob Heald maintained the study during the initial stages. John Battles of UC Berkeley, Julianne Stewart and Ryan Stewart of Southern California Edison and Ken Somers of Blodgett Forest provided useful reviews. Dennis Hall of Cal Fire provided timber harvest plan data. UC Center for Forestry provided support.

\section{References}

Angers VA, Messier C, Beaudet M, Leduc A. 2005. Comparing composition and structure in old-growth and harvested (selection and diameter-limit cuts) northern hardwood stands in Quebec. Forest Ecol Manag 217:275-93

Ansley JS, Battles JJ. 1998. Forest composition, structure and change in an old-growth mixed conifer forest in the northern Sierra Nevada. J Torrey Bot Soc 125:297-308.

Barbour MG, Keeler-WolfT, Schoenherr, AA. 2007. Terrestrial Vegetation of California. Berkeley, CA: UC Press.

Buongiorno J, Kolbe A, Vasievich M. 2009. Economic and ecological effects of diameter-limit and BDq management regimes: Simulation results for northern hardwoods. Silva Fenn 34:223-35.

[Cal Fire] California Department of Forestry and Fire Protection. 2010. FRAP: California's Forest and Rangelands Assessment. $343 \mathrm{p}$

Daniel TW, Helms JA, Baker FS. 1979. Principles of Silviculture. New York: McGraw-Hill.

Eitzel MV, Battles JJ, York RA, et al. 2013. Estimating tree growth models from complex forest monitoring data. Ecol Appl 23:1288-96.

Erickson MD, Reed DD, Mroz GD. 1990. Stand development and economic analysis of alternative cutting methods in northern hardwoods: 32-year results. N Appl For 7:153-8.

Ford DE. 2007. Scientific Method for Ecological Research. Cambridge: Cambridge University Press. 588 p.

Franklin JF, Spies TA, Van Pelt R, et al. 2002. Disturbances and structural development of natural forest ecosystems with silvicultural implications, using Douglas-fir forests as an example. Forest Ecol Manag 155:399-423. Gersonde R, O'Hara KL. 2005. Comparative tree growth efficiency in Sierra Nevada mixed-conifer forests. Forest Ecol Manag 219:95-108.

Hagmann RK, Franklin JF, Johnson KN. 2013. Historical structure and composition of ponderosa pine and mixed-conifer forests in south-central Oregon. Forest Ecol Manag 304:492-504.

Hawley GJ, Schaberg PG, DeHayes DH, Brisette JC. 2005. Silviculture alters the genetic structure of an eastern hemlock forest in Maine, USA. 2005. Can J Forest Res $35 \cdot 143-50$
Kenefic LS, Sendak PE, Brissette JD. 2005. Comparison of fixed diameter-limit and selection cutting in northern conifers. North J Appl For 22:77-84.

Kern CC, Palik BJ, Strong TF. 2006. Ground-layer plant community responses to even-aged and uneven-age silvicultural treatments in Wisconsin northern hardwood forests. Forest Ecol Manag 230:162-70.

Lutz JA, van Wagtendonk JW, Franklin JF. 2009. Twentieth-century decline of large-diameter trees in Yosemite National Park, California, USA. Forest Ecol Manag 257:2296-307. doi:10.1016/j.foreco.2009.03.009.

O'Curtis R, Marshall DD, Bell JF. 1997. LOGS: A pioneering example of silvicultural research in coast Douglas-fir. J Forest 95:19-25.

Stephens SL, Collins BM. 2004. Fire regimes of mixed conifer forests in the North-Central Sierra Nevada at multiple spatial scales. Northwest Sci 78:12-23.

Stephenson NL, Das AJ, Condit R, et al. 2014. Rate of tree carbon accumulation increases continuously with tree size. Nature 507:90-3. doi:10.1038/nature12914.

Wensel LC, Daugherty PJ, Meerschaer WJ. 1986. CACTOS user's guide: The California conifer timber output simu lator. Bulletin 1920. Oakland: UC Division of Agricultural Sciences.

York RA, Battles JJ, Wenk R, Saah D. 2011. A gap-based approach for regenerating pine species and reducing surface fuels in multi-aged mixed conifer stands in the Sierra Nevada, California. Forestry 85:203-13. dol:10.1093/forestry/cpr058.

York RA, Fuchs D, Battles JJ, Stephens SL. 2010. Radial growth responses to gap creation in large, old Sequoiadendron giganteum. Appl Veg Sci 13:498-509. doi:10.1111/j.1654-109X.2010.01089.X

York RA, Heald RC, Battles JJ, York JD. 2004. Group selection management in conifer forests: Relationship between opening size and tree growth. Can J Forest Res 34:630-41.

Zar JH. 1999. Biostatistical Analysis (4th ed.). New Jersey: Prentice Hall.

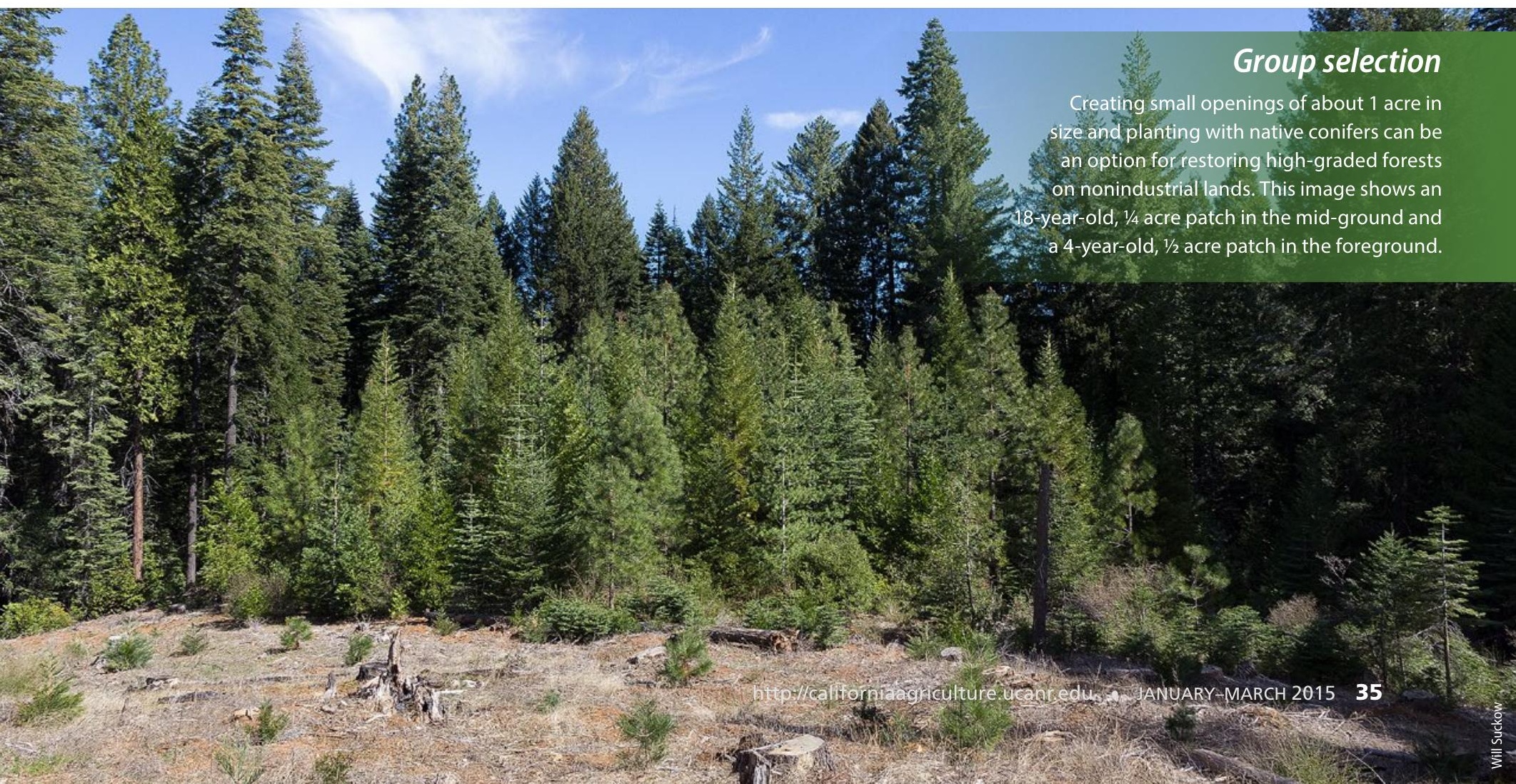

